\title{
Representações sociais na internet sobre cotas para negros em universidades federais
}

\author{
Social representations on the internet about racial quotas at the \\ Federal Universities
}

\author{
Amanda Castro ${ }^{1}$ \\ Larissa Papaleo Koelzer ${ }^{2}$ \\ Brigido Vizeu Camargo ${ }^{3}$ \\ Andréa Barbará S. Bousfield ${ }^{4}$
}

\begin{abstract}
Resumo
O presente estudo teve como objetivo investigar as representações sociais das cotas para negros em universidades federais, destacadas em comentários na internet, acerca de um artigo difundido online por meio do site de uma revista de circulação nacional. Para este estudo de caráter exploratório e descritivo foram selecionados para análise 272 comentários, apresentados por indivíduos diferentes, excluindo postagens que não fizessem menção aos conteúdos presentes na reportagem. Eles foram organizados em um único corpus que foi submetido a uma Classificação Hierárquica Descendente (CHD) simples, com o auxílio do programa informático IRAMUTEQ. A CHD reteve 211 textos, $77,29 \%$ do total, e dividiu o corpus em quatro classes. Os resultados, presentes nas classes, referem-se às representações sociais de cotas para negros a partir da discussão do mérito, igualdade e aspectos históricos que justifiquem a favorabilidade ou desfavorabilidade do indivíduo referente a esta ação afirmativa.
\end{abstract}

Palavras-chave: Representações Sociais. Cotas. Negros. Universidades.

\section{Abstract}

This study aimed to investigate the social representations of racial quotas at the Federal Universities, featured on the comments of internet, about an online article publicized on the website of a national journal. For this exploratory and descriptive study, we selected 272 comments for analysis that were submitted by different individuals. We excluded posts that do not refer to the content of the report. They were organized into a corpus that was submitted to a simple Descending Hierarchical Classification (CHD) with the aid of the software IRAMUTEQ. The CHD retained 211 texts, $77.29 \%$ of the total, and divided the corpus into four classes. The results present in the classes refer to the social representations of racial quotas from the discussion of the merit; the equality and the historical aspects that justify the favorability or (des)favorability of the individual regarding this affirmative action.

\footnotetext{
${ }^{1}$ Universidade Federal de Santa Catarina (UFSC). Mestranda do Programa de Pós-Graduação em Psicologia da UFSC. E-mail: amandacastrops@gmail.com.

${ }^{2}$ Universidade Federal de Santa Catarina (UFSC). Mestranda do Programa de Pós-Graduação em Psicologia da UFSC. E-mail: larissapk@hotmail.com.

${ }^{3}$ Universidade Federal de Santa Catarina (UFSC). Professor do Programa de Pós-Graduação em Psicologia da UFSC. E-mail: brigido.camargo@gmail.com.

${ }^{4}$ Universidade Federal de Santa Catarina (UFSC). Professora do Programa de Pós-Graduação em Psicologia da UFSC. E-mail: andreabs@gmail.com.
} 
Keywords: Social Representation. Quotas. Blacks. Universities.

\section{Introdução}

No meio científico e na sociedade em geral, diversos posicionamentos têm surgido sobre as cotas para negros em universidades federais. Este tema vem obtendo visibilidade através dos meios de comunicação, especialmente pela internet. Essas diversas posições encontram justificativas nos variados argumentos existentes a favor ou contra as cotas como políticas de ação afirmativa. Diversos estudos têm sido realizados sobre cotas para negros na universidade, em que os autores abordam as desigualdades educacionais e sociais entre negros e brancos (DURHAM, 2003), propõem reflexões teóricas acerca das ações afirmativas e cotas nos vestibulares das universidades públicas (BALBINO, 2004), e analisam elementos de representações sociais em relação aos diversos tipos de políticas de cotas (NAIFF; NAIFF; SOUZA, 2009). Desse modo, estudos relativos ao universo consensual e ao universo reificado são relevantes para a compreensão desse objeto social. 5

Nos universos consensuais a sociedade se vê como um grupo feito de indivíduos que são de igual valor e que gradualmente criam formas habituais de realizar algumas práticas, como uma comunidade de significados entre aqueles que participam dela, em que se busca estar protegido das áreas de discordância e de incompatibilidade. Já nos universos reificados, a sociedade se concebe como um sistema com diferentes papéis e categorias, cujos ocupantes estão em grupos estratificados, em que o grau de participação é determinado pelo nível de qualificação (MOSCOVICI, 2003). As questões relativas à epistemologia procuram discutir como a ciência mediante sua difusão na sociedade torna-se conhecimento do senso comum em que as pessoas estão cientes de seus problemas, atuam na vida cotidiana e tomam decisões. A noção de representação social é concebida

\footnotetext{
${ }^{5}$ Moscovici explica que existem dois universos de pensamento nas sociedades, o universo reificado e o universo consensual. $O$ universo reificado é considerado o conhecimento produzido com rigor lógico, objetividade e metodologia características da ciência. Portanto, ele está relacionado com o espaço científico. O universo consensual se constitui principalmente pelas atividades intelectuais da interação social, nas conversas informais, e é nesse contexto em que as representações sociais são formuladas (MOSCOVICl, 2001).
} 
para explicar o que une as pessoas a um grupo ou a uma sociedade e os faz agir em conjunto (PALMONARI; CERRATO, 2011).

As representações sociais, enquanto forma de conhecimento, possuem finalidade até certo ponto opostas à do conhecimento científico. Contarello (2007) ressalta que a ciência traça o caminho inverso, buscando estranhar fenômenos que, à primeira vista, são familiares ou inteligíveis, para chegar a conhecimentos válidos. O que é proposto pela teoria das representações sociais é um estudo científico do senso comum. Por sua vez, o senso comum é objeto de estudo da psicologia social porque, de acordo com Doise (1985), essa modalidade de conhecimento varia conforme inserções específicas num contexto de relações sociais, isto é, essa forma de conhecimento está ligada à realidade dos grupos e categorias sociais, capacitando seus membros com uma visão de mundo e contribuindo para sua identidade social. Conforme definição de Jodelet (2001, p. 22), a representação social "[...] é uma forma de conhecimento, socialmente elaborada e partilhada, com um objetivo prático, e que contribui para a construção de uma realidade comum a um conjunto social". Considerando que o caráter de conhecimento está ligado à realidade dos grupos e categorias sociais, a teoria de representações sociais pode auxiliar na compreensão acerca das teorias de senso comum sobre objetos diversos, dentre eles podemos considerar as políticas de ações afirmativas, como o sistema de cotas para negros em universidades federais.

De acordo com Bayma (2012) políticas de ações afirmativas são medidas públicas ou privadas, de caráter coercitivo ou não, que visam promover a igualdade substancial, através de discriminação positiva de pessoas integrantes de grupos que estejam em situação desfavorável e que sejam vítimas de discriminação e estigma social. As políticas de ação afirmativa têm como meta tratar de maneira diferente os diferentes, minimizando as formas de discriminação que impeçam o acesso a oportunidades e benefícios, não se confundindo com o sistema de cotas (TRAGTENBERG et al., 2006).

\section{As ações afirmativas e o sistema de cotas}

As ações afirmativas não se confundem com o sistema de cotas, mas o abrangem, pois conforme Neves e Lima (2007), toda ação, seja ela pública ou 
privada que, reconhecendo uma situação desfavorável a uma minoria, procura atingir uma situação de igualdade, pode ser caracterizada como uma ação afirmativa. Munanga (2004) esclarece que as chamadas políticas de ação afirmativa são muito recentes na história da ideologia antirracista e nos países onde já foram implantadas (Estados Unidos, Inglaterra, Canadá, Índia, Alemanha, Austrália, Nova Zelândia e Malásia, entre outros), visam oferecer aos grupos discriminados e excluídos um tratamento diferenciado para compensar as desvantagens decorrentes de discriminação ou racismo.

Bittar e Almeida (2006) realizaram uma pesquisa com o objetivo de analisar o processo de implantação da política de cotas para negros na educação superior na Universidade Estadual de Mato Grosso do Sul. Para tanto, entrevistaram os alunos que ingressaram pelo sistema de cotas para negros no Processo Seletivo 2004 (vestibular realizado em dezembro de 2003), nos cursos de Direito e Enfermagem. Os autores demonstram em sua pesquisa que para os cotistas as cotas são um direito que oportuniza aos negros o acesso à educação superior, sendo meio primordial para o ingresso na Universidade. Tais dados evidenciam também o difícil acesso às universidades federais antes da política de cotas para negros.

Para Azevedo (2004) a cor (ou pertencimento racial) que alguém se atribui é confirmada ou negada pelo olhar do outro. Desse modo, raça seria um conceito social, ou seja, é como a sociedade vê e trata o sujeito e não se efetivamente ele é da raça negra, branca ou amarela (BARROS; BARROS; RÊGO, 2010). Brandão e Marins (2007) destacam em sua pesquisa que os alunos de Ensino Médio são, em grande medida, contrários à política de cotas para negros na universidade por identificá-la como uma medida discriminatória, apesar de que alguns possam ser beneficiários dela.

Queiroz e Santos (2006) demonstram, por meio de suas pesquisas, que em geral os indivíduos apoiam a proposta de cotas para negros em universidades federais e que, entre os que rejeitam a proposta, a maioria tem curso superior e renda familiar mensal acima de dez salários mínimos. Munanga (2007) descreve os principais argumentos contrários à adoção de cotas para negros, em universidades federais, utilizados no senso comum e também entre pesquisadores. Dentre as características dos elementos de tais representações, Munanga (2007) cita a questão da miscigenação, visto que alguns indivíduos salientam a impossibilidade 
de implementar cotas para negros no Brasil devido à dificuldade de definição sobre quem seria negro. Outro argumento contrário às cotas para negros, de acordo com não cotistas, diz respeito à grande concorrência pelas vagas; pois as cotas poderiam perigosamente estimular os preconceitos, diferenças e facilidades para uns em detrimento a outros (MUNANGA, 2007). Em pesquisa desenvolvida por Queiroz e Santos (2006), os elementos das representações contrárias ao sistema de cotas indicavam: preocupação com a divisão racial no país, dificuldades que os estudantes cotistas encontrariam nos cursos, reforço da ideologia da mestiçagem em contraponto à utilização do conceito de raça, comprometimento da qualidade do ensino na universidade e, por consequência, da manutenção do mérito.

Augoustinos, Tuffin e Every (2005), em seus estudos, conduziram dois grupos focais, com estudantes universitários australianos não aborígenes, sobre os programas de ações afirmativas voltadas aos estudantes indígenas. Como principais resultados desse estudo, os autores destacaram que os indivíduos percebem e relatam as dificuldades que os indígenas enfrentam na sociedade; por outro lado fazem forte oposição à ação afirmativa, apoiados no principio da meritocracia, nas diferenças entre o grupo de cotistas e não cotistas relativas à realidade social, e também na questão do sentimento de injustiça em decorrência de certo favorecimento. Assim, é possível verificar que tais representações apareciam em paralelo, influenciadas pelo fenômeno de desejabilidade social e pela identidade social.

\section{A internet como vetor de circulação das representações sociais}

Para Tajfel (1983) as características que permitem a identificação dos membros dos grupos adquirem seu significado através da comparação social. Esse processo produziria uma influência sobre a autoestima, a partir de uma relação com a diferenciação positiva do próprio grupo (ingroup) quando se compara com os demais (outgroups). Tais comparações, do tipo auto avaliativo, podem se apresentar por meio de processos competitivos que motivam atitudes e ações discriminatórias em relação aos grupos externos.

A implantação da política de cotas para negros em universidades federais suscita discussões nos diversos segmentos da sociedade, nas pautas políticas, 
jurídicas e ideológicas, ganhando espaço nas discussões cotidianas por meio da veiculação de informações na internet, nas revistas e na televisão. Camargo (2003) indica que a presença dos meios de comunicação social é cada vez mais intensa no modo de vida contemporâneo, especialmente no que se refere à circulação de objetos do debate social. Desse modo, torna-se relevante o estudo das representações sociais, considerando os elementos relativos aos posicionamentos favoráveis e desfavoráveis acerca das cotas para negros, bem como estabelecer relação com a veiculação de informações sobre cotas para negros por meio de notícias online.

Ao visitar as páginas e comunidades na internet, é possível reafirmar, conforme Tajfel (1972), que todas as pessoas pertencem a uma grande quantidade de posições sociais não excludentes entre si. As pessoas não se orientam por uma única representação social frente a um dado objeto social, mas potencialmente por tantas quantas sejam os grupos de que os indivíduos tomam parte, considerando que algumas dessas pertenças são mais importantes que outras para o indivíduo (WACHELKE; CAMARGO, 2007).

No século $X X I$, a internet se constitui como uma das principais fontes de comunicação e, com sua intensa e rápida possibilidade de troca de informações, permite uma relação fluida de troca de papéis entre o produtor e o receptor da informação. Assim, torna a informação independente de seu produtor, permite diálogos entre pessoas e grupos, constituindo-se em um espaço para discussão e elaboração de representações (SAAD, 2003). De acordo com Moscovici (1981) e Rouquette (1986), a comunicação de massa constitui uma maneira dinâmica de elaborar representações sociais, pois disponibiliza, a cada dia, muito material e conteúdo no cotidiano dos indivíduos e dos grupos. Conforme Wolf (1999, p. 144), a pessoa elabora seu conhecimento, em parte, de acordo com o conteúdo dos meios de comunicação, que também têm a função de classificar a importância de um fato e definir se um assunto fará ou não parte de seu cotidiano. Desse modo, "a comunicação social é um processo cada vez mais determinado pelos meios de comunicação" (RÜDIGER, 2011, p. 118). Nesse sentido, a internet parece se constituir em um dos meios de comunicação de massa mais utilizados nos últimos anos. 
Ao falar sobre comunicação de massa, Kientz (1973, p. 18) reafirma seu caráter unilateral durante o período Industrial, em que uma minoria produzia mensagens para que a grande massa as recebesse em silêncio. Na era digital, o modelo de comunicação da internet apresenta as relações de pertencimento a partir da interatividade, em que o receptor pode tornar-se emissor e vice-versa. A formação de redes sociais e comunidades on-line constitui um espaço de troca de informações, suscitando discussões que permitem o estudo sobre elementos representacionais de diversos objetos. Dentre esses diversos objetos, destaca-se aqui a temática cota para negros em universidade federais. Este estudo tem como objetivo investigar as representações sociais das cotas para negros em universidades federais, inscritas em comentários gerados por leitores sobre um artigo publicado de forma on-line, referente a uma reportagem impressa publicada em uma revista de circulação nacional.

Diante dessa temática este estudo pretende investigar algumas questões:

- $\quad$ o que as pessoas pensam sobre cotas para negros em universidades federais?;

- $\quad$ o modo como as pessoas pensam a política de cotas influencia em um posicionamento favorável ou desfavorável a essa medida?; e

- as representações sociais de cotas para negros explícitas em comentários on-line apresentam elementos semelhantes àquelas identificadas em estudos realizados com outros métodos de coleta?

O artigo em questão foi intitulado "Por que as cotas raciais deram certo no Brasil", e veiculado no site de uma conhecida revista de distribuição nacional. Neles são apresentados relatos de universitários cotistas que contam sua trajetória até a universidade. Além disso, o artigo apresenta uma concepção positiva em relação às cotas, como no seguinte excerto: "as cotas raciais deram certo porque seus beneficiados são, sim, competentes. Merecem, sim, frequentar uma universidade pública e de qualidade."

\section{Método}

Para este estudo, foram selecionados comentários gerados por leitores de um artigo de uma revista de circulação nacional sobre cotas para negros em 
universidades federais. O artigo utilizado (edição de número 2264) foi disponibilizado em 5 de abril de 2013, de forma on-line no site da revista. Ele gerou 335 comentários de leitores por meio da internet. Cabe ressaltar que a divulgação da notícia apresentava o sistema de cotas para negros enquanto ação afirmativa de sucesso, destacando casos de cotistas que tiveram ascensão acadêmica e profissional.

Dentre os 335 comentários, postados até 8 de maio de 2013, foram selecionados para análise 272, apresentados por diferentes indivíduos, excluindo postagens que não fizessem menção aos conteúdos presentes na reportagem. Os comentários foram organizados em um único corpus que foi submetido a uma Classificação Hierárquica Descendente (CHD) simples com o auxílio do programa informático IRAMUTEQ versão 0.6. De acordo com Camargo e Justo (2013), essa análise visa obter classes de Segmentos de Texto (ST) que, ao mesmo tempo, apresentam vocabulário semelhante entre si e vocabulário diferente dos ST das outras classes. Esse programa informático, gratuito, viabiliza diferentes tipos de análise de dados textuais, desde aqueles bem simples, como a lexicografia básica como cálculo de frequência de palavras, até análises multivariadas como classificação hierárquica descendente e análises de similitude (CAMARGO; JUSTO, 2013).

A Classificação Hierárquica Descendente (CHD), além de permitir uma análise lexical do material textual, oferece contextos (classes lexicais), caracterizados por um vocabulário específico e pelos segmentos de textos que compartilham esse vocabulário (CAMARGO, 2005). Os segmentos de texto são classificados em função dos seus respectivos vocabulários e o conjunto deles é repartido em função da frequência das formas reduzidas.

$\mathrm{Na}$ Classificação Hierárquica Descendente (CHD) cada classe é constituída de vários segmentos de texto com classificação segundo a distribuição do vocabulário (formas) desses segmentos (CAMARGO; JUSTO, 2013). As classes geradas a partir da classificação hierárquica descendente representam o contexto de sentido das palavras e podem apontar representações sociais ou elementos de representações sociais sobre o objeto social estudado (CAMARGO, 2005). Após a Classificação Hierárquica Descendente (CHD) simples, foram considerados para inserção em cada classe os elementos cuja frequência fosse maior que a média de 
ocorrências no corpus e que a associação com a classe determinada pelo valor de qui-quadrado fosse igual ou superior a 3,84 .

\section{Resultados}

O conteúdo do corpus compreende posicionamentos neutros, favoráveis e/ou desfavoráveis à reportagem sobre o sucesso da política de cotas para negros em universidades federais. O programa IRAMUTEQ reconheceu a separação do corpus em 272 textos ou comentários. A CHD reteve 211 textos, $77,29 \%$ do total, e dividiu o corpus em quatro classes, conforme indica a Figura 1.

Figura 1: Dendograma de classes sobre as as representações sociais das cotas para negros em universidades federais

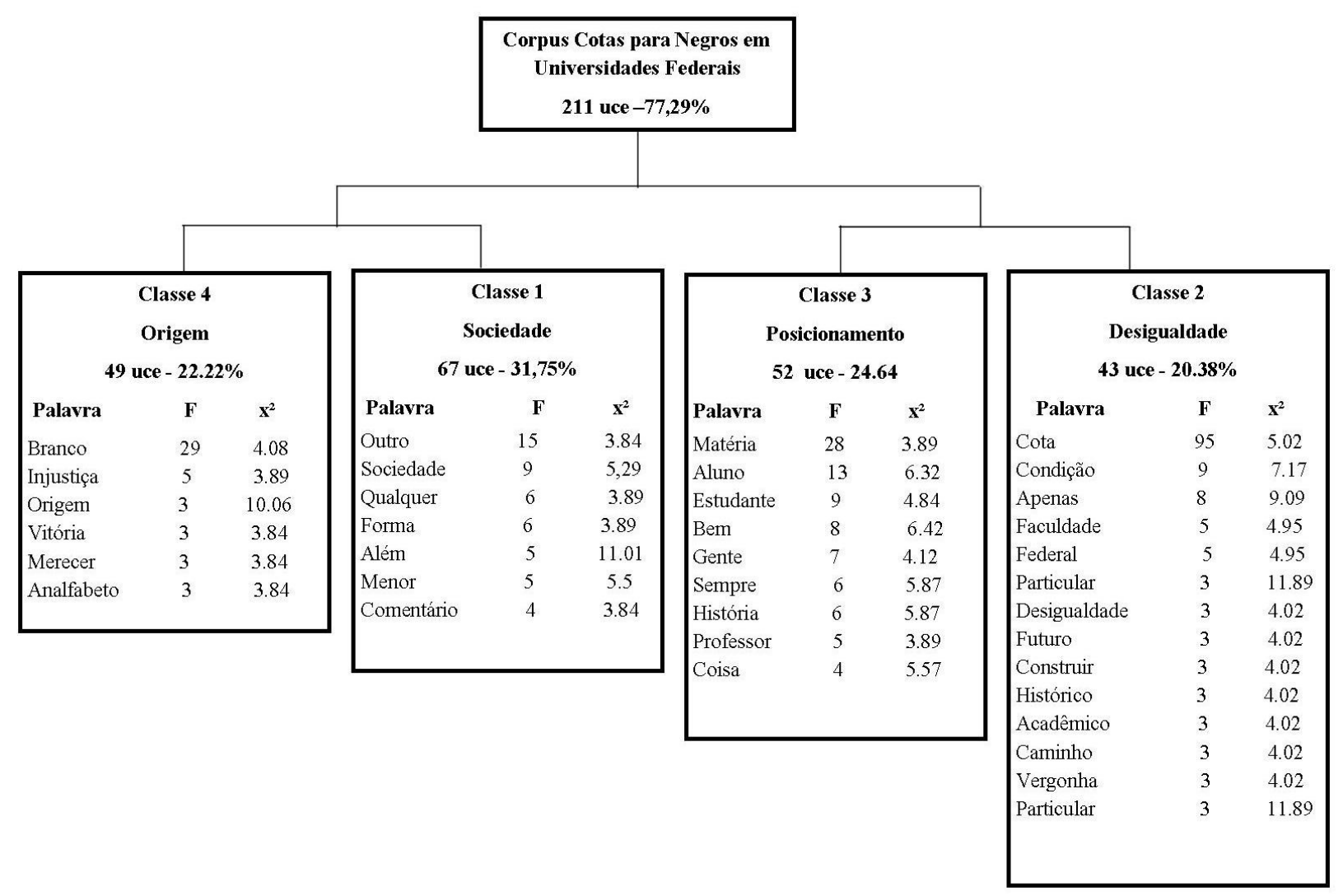

Fonte: Elaboração própria.

Num primeiro momento ( $1^{\mathrm{a}}$ partição), o corpus foi separado em dois subcorpus (de um lado um conjunto formado pelas futuras classes 4 e 1 , e do outro pelo conjunto do que se tornaria nas classes 3 e 2). Uma $2^{a}$ partição gerou as classes 4 e 1; e uma $3^{a}$ partição, as classes 3 e 2.

Cad. de Pesq. Interdisc. em Ci-s. Hum-s., Florianópolis, Santa Catarina, ISSN 1984-8951 v.15, n.106, p. 202-220 - jan./jun. 2014 
A classe Sociedade (Classe 1), com maior quantidade de comentários $(31,75 \%)$, traz referências à política, ao direito, à discriminação, apontando condições sociais que favorecem ou dificultam o ingresso em universidades federais. Os elementos que compõem essa classe sugerem uma crítica ao ensino público e ao sistema de cotas como uma política ou direito que transcende as discussões sobre a validade de ações afirmativas, pois favorece ou dificulta a igualdade social:

\begin{abstract}
Sou contra as cotas e represento negros que são contra porque estudaram em escolas públicas se esforçaram para faculdade antes das cotas e depois na seleção das empresas se compara eles com as cotas, com esforço menor, será necessário anexar o resultado do vestibular no currículo (comentário 3).

Porque os jovens que concluírem o ensino médio nas escolas públicas na grande maioria continuarão saindo analfabetos funcionais (comentário 155).
\end{abstract}

A classe 4, denominada Origem, apresenta 22,22\% do total de comentários. Seus elementos estão relacionados principalmente ao posicionamento dos indivíduos em relação às cotas para negros, a partir da ênfase nas diferenças sociais entre negro e branco. Seu conteúdo engloba palavras como: injustiça, analfabeto, origem e branco, conforme os exemplos:

Concordo e apoio em relação às cotas por baixa renda, essa história de racial é ridículo, as provas medem o nível de conhecimento, sendo que negros e brancos estão no mesmo nível de aprendizado em escolas públicas (comentário 11).

No fundo o que muitos brancos temem é que os negros ocupem o seu lugar ou o de seus filhos na universidade. Não há outra palavra para expressar isso a não ser racismo (comentário 84).

Em oposição às classes 1 e 4, estão as classes 3 e 2. A classe Posicionamento (Classe 3) representa $24,64 \%$ do total de comentários. Essa classe apresenta elementos relativos, principalmente, ao posicionamento do governo, dos professores, das universidades e da própria revista em relação aos alunos negros. É importante frisar que os elementos presentes nos comentários dessa classe não estão relacionados à política de cotas em si, mas sim às instâncias que se posicionam publicamente a favor ou contra o sistema de cotas para negros, como nos excertos:

Os professores das universidades federais podem atestar o desempenho de seus alunos cotistas e não cotistas. Por que não fazer uma reportagem

Cad. de Pesq. Interdisc. em Ci-s. Hum-s., Florianópolis, Santa Catarina, ISSN 1984-8951 v.15, n.106, p. 202-220 - jan./jun. 2014 
idônea mostrando isso? O mundo lá fora desta redoma é da meritocracia: prosperam os bons e isso independe da cor (comentário 35).

Engraçado, mas tudo que o governo faz para os pobres é compra de votos. Mas vou dizer uma coisa, prefiro que o governo use dinheiro para comprar milhões de votos do que dar para meia dúzia de amiguinhos (comentário 38).

A Classe 2, denominada Desigualdade, representa 20,38\% dos comentários retidos na análise. Seu conteúdo abrange aspectos da desigualdade relacionados à qualidade de ensino, condição socioeconômica e acesso ao ensino particular. A desigualdade nessa classe representa uma justificativa em relação à favorabilidade ao sistema de cotas. Percebe-se a intensidade de elementos relativos à desigualdade de acesso a bens e serviços nos comentários que pertencem a essa classe, conforme o excerto:

belíssima reportagem. A desigualdade de oportunidades entre as raças é um círculo vicioso histórico que precisa urgentemente ser quebrado e o sistema de cotas são uma solução prática para isso (comentário 69).

Nessa classe, estão presentes também elementos que fazem alusão à qualidade de ensino, em que há a oposição entre ensino público e ensino privado, tendo em vista que o ensino público apresentaria nível inferior em relação ao ensino privado, e mais uma vez essa relação desigual justificaria a favorabilidade ao sistema de cotas, conforme o comentário 148, a seguir:

\footnotetext{
Sou a favor das cotas, mas acredito que deveria ser uma política com prazo determinado até que as escolas públicas estivessem no mesmo nível das particulares. Só assim as oportunidades seriam iguais. De qualquer forma a população negra ainda enfrenta um muro invisível que fecha muitas portas (comentário 148).
}

Desse modo, na classe 2, há a presença de maior favorabilidade ao sistema de cotas. Nessa classe, estão presentes 37 comentários que apresentam elementos a favor do sistema de cotas como medida provisória, justificada pela desigualdade entre ensino público e ensino privado. Em relação às demais classes, não há prevalência geral em relação à favorabilidade ou à desfavorabilidade ao sistema de cotas para negros em universidades federais. A maioria dos participantes (127 comentários) apresenta posicionamento neutro em relação à política de cotas, não se posicionando diretamente a favor ou contra as cotas para negros em universidades federais. Os comentários com posicionamento neutro não mostram 
implicação pessoal que remeta à favorabilidade ou à desfavorabilidade do internauta, sendo seu foco a discussão de aspectos políticos e sociais.

\section{Discussão}

A análise dos dados indica a predominância de uma ambivalência nos posicionamentos dos indivíduos. Alguns podem ser considerados favoráveis à implantação das cotas raciais enquanto outros podem ser considerados desfavoráveis. Os argumentos contrários às cotas defendem, prioritariamente, a ideia de que elas ferem o princípio da meritocracia, constituindo-se numa medida meramente assistencialista. Entretanto, embora haja algumas discordâncias quanto à necessidade de implantação da política de cotas para negros, há também aqueles que acreditam que as desigualdades socioeconômicas estão relacionadas à origem étnico-racial, como foi encontrado no estudo de Neves e Lima (2007).

Guimarães (1999) afirma que a discussão acerca das políticas de ações afirmativas, como as cotas universitárias, está inserida no debate de duas perspectivas. A perspectiva histórica e sociológica é voltada para a compreensão de antecedentes sociais e históricos para a justificativa de ações afirmativas. A segunda perspectiva, de ordem "axiológica e normativa", constitui-se numa crítica acerca da correção ou não do tratamento diferenciado aos indivíduos baseado nas suas características individuais e grupais. Essa perspectiva defende e prioriza o mérito individual em detrimento da pertença social ou grupal, o que pode também ser observado nos comentários encontrados na Classe 3.

Silva e Silva (2012) estudaram as representações sociais de estudantes universitários sobre as cotas e encontraram discursos parecidos com os pertencentes à Classe 1 , que trazem a questão das falhas na educação pública. Rodrigues (2006) afirma que o vestibular assume o papel de instrumento privilegiado na seleção dos melhores, dos mais capacitados para o acesso ao espaço acadêmico. Assim, a defesa do mérito acadêmico e da manutenção da qualidade do ensino universitário parece ser a preocupação central. Com posicionamento contrário às cotas raciais, os estudantes consideram que a dificuldade em ingressar numa universidade pública, pelo processo vestibular, é decorrente da precariedade da educação básica. Considerando que a educação básica de qualidade deveria ser 
uma das prioridades do governo, de acordo com os participantes, seria desnecessária a adoção da política de cotas nas universidades, tanto para os negros quanto para os alunos provenientes de escolas públicas, aspectos que podem ser visualizados nos elementos apresentados nas Classes 2 e 4.

$\mathrm{Na}$ classe 2, os elementos relativos à desigualdade envolvem os aspectos históricos que influenciam no atual contexto social de igualdade. Alguns participantes destacam a desigualdade tendo em vista a divisão por etnia em relação às cotas. Outros consideram a desigualdade tendo em vista o processo de escravidão e marginalização social, em que o sistema de cotas é compreendido como uma condição temporária necessária. Dados semelhantes foram encontrados por Queiroz e Santos (2006), em que os argumentos favoráveis apontam para uma medida social provisória, e os argumentos contrários à introdução do sistema de cotas indicam preocupações com o futuro do país em se tornar uma sociedade dividida por raças. Considerando posicionamentos favoráveis ou desfavoráveis, nessa classe, é feita menção à necessidade de melhoria do ensino público como medida necessária ao desenvolvimento do país.

A classe 4 enfatiza alguns aspectos chamados efeitos "colaterais" das políticas afirmativas. Conforme Lorenzi-Cioldi e Buschini (2005), pode haver aumento da atribuição de estereótipos, depreciação dos indivíduos beneficiários dessa políticas, manifestação de dúvidas sobre o próprio desempenho, contribuindo para o aumento da atribuição, pelo próprio indivíduo, de causas externas ao seu sucesso. Ainda sobre a classe 4 , os resultados são parecidos com os encontrados por Lorenzi-Cioldi (2002) e Lorenzi- Cioldi e Buschini (2005) em suas pesquisas sobre os efeitos das políticas afirmativas para mulheres na Suíça e na França. Esses autores propõem que políticas de ações afirmativas direcionadas a grupos mais amplos, como aqueles de baixo nível socioeconômico, são mais aceitas do que aquelas que visam beneficiar grupos mais restritos baseados em diferenças étnicas ou raciais. Aqueles que as percebem como um privilégio atribuem à medida um caráter inconstitucional, pois favoreceria um grupo em detrimento de outro e estaria em oposição à ideia de mérito individual; o que também contribuiria para a inferiorização do grupo supostamente beneficiado, que seria visto como menos capaz. Ainda nessa classe constam elementos que caracterizam as cotas como um direito relativo à origem. Moehlecke (2002) afirma que, para os que entendem as 
cotas para negros em universidades federais como um direito, elas estariam de acordo com os preceitos constitucionais, pois procurariam corrigir uma situação real de discriminação e não seriam contrárias às representações sociais de mérito individual. Isso porque teriam como meta fazer com que o mérito possa efetivamente existir, tendo em vista que, atualmente, a sociedade brasileira seria incapaz de garantir que as pessoas vençam por suas qualidades e esforços.

As pesquisas em comunicação geralmente visam verificar o efeito que um determinado conteúdo tem em seus receptores. No entanto, o conteúdo da mensagem é somente um dos elementos importantes que determinam seu efeito, pois as condições do receptor e suas relações e normas sociais influenciam na forma como a mensagem é recebida, reapropriada e avaliada (WOLF, 1999). Nesse sentido, por mais que o artigo da revista tenha divulgado as cotas para negros em universidades federais como um sucesso, os leitores, por meio de seus comentários, não pareceram muito propensos à aceitação da medida. A favorabilidade à medida provisória não foi fator preponderante nos comentários gerados, não apresentando diferenças relevantes a serem destacadas. É necessário considerar a internet como um espaço no qual os polos emissor e receptor alternam de funções, numa relação de troca simultânea e fluida em que o indivíduo que a utiliza tem acesso a uma diversidade de informações sobre um mesmo objeto, podendo se posicionar de acordo com seus grupos de pertença. Dessa forma, as normas e as relações de pertença parecem adquirir, na internet, um caráter relevante, ao propiciar uma participação ilimitada de autores e leitores numa multiplicidade aberta de pontos de vista, constituindo um espaço privilegiado para a manifestação de representações sociais.

\section{Considerações finais}

As representações sociais acerca da reserva de vagas para alunos negros em universidades federais não apresentam elementos consensuais, pois enquanto alguns participantes se referem às cotas como um dever social, outros afirmam que o sistema de cotas vai contra o sistema voltado à meritocracia, estando vinculado à característica de privilégio. O debate acerca das cotas raciais em universidades 
públicas brasileiras parece estar permeado por argumentos tanto a favor como contra sua implantação.

A maioria das opiniões contra esse sistema se apoia na hipótese de que as cotas são identificadas como uma solução paliativa para uma deficiência ou incapacidade individual. Vistas dessa maneira, as cotas poderiam ser consideradas uma injustiça por falsear a real capacidade dos candidatos, além de um estigma que causaria discriminação e conflitos raciais.

Além disso, de acordo com Neves e Lima (2007), outra razão que pode influenciar a resistência ao sistema de cotas é que elas visam o indivíduo e não a coletividade. Porque, embora esse sistema tenha sido elaborado para resolver uma questão atinente a um grupo específico, o dos negros, as cotas têm beneficiado individualmente os negros mais bem preparados pelo sistema educacional (NEVES; LIMA, 2007). Assim, em relação às cotas, as representações que não apresentam explicitamente favorabilidade ou desfavorabilidade trazem elementos referentes à responsabilidade da revista e do governo a respeito da publicação de informações fidedignas e imparciais sobre o sistema de cotas, citando a matéria da referida revista como "tendenciosa".

Por um lado as representações contrárias às cotas apontam que essa medida provisória seria um reconhecimento de que não há mudança possível nas condições de vidas dos pobres, incluindo-se aqui os negros. Esse sistema poderia implicar uma mobilidade social dos negros e não uma mudança social. Por outro lado, a pressão social e o debate sobre as cotas podem denotar uma maior responsabilização do governo brasileiro por essas questões, embora elas possam ter se tornado uma mera forma de, mesmo com insuficiente investimento na educação pública, solucionar a desigualdade racial no acesso ao ensino superior. Ainda assim, segundo Neves e Lima (2007), essas medidas são associadas à caridade, como uma forma de melhorar a vida da coletividade, uma vez que o benefício concedido a um indivíduo deve significar melhoria da vida coletiva. De qualquer forma, pode-se considerar que as representações sociais sobre o sistema de cotas refletem aspectos do individualismo, a partir do princípio da meritocracia, e aspectos do altruísmo, quando associadas à caridade.

É necessário considerar que a implantação da política de cotas para negros em universidades federais já ocasionou importantes discussões no meio científico, 
discussões essas que têm sido gradualmente ampliadas e projetadas também para o senso comum. E se verifica que ainda não há um consenso no meio científico ou no meio social acerca da validade da implantação do sistema de cotas, o que justifica a relevância do desenvolvimento de pesquisas que envolvam essa temática, a qual suscita tantos debates e, consequentemente, propicia o contexto para o estudo de elementos representacionais acerca desse objeto.

Como este estudo teve como foco apenas as representações sociais sobre cotas para negros em universidades federais difundidas na internet, levando em conta que esta propicia uma maior exposição sem aparentes consequências sociais, é possível que os indivíduos que apresentaram posicionamentos contrários ao conteúdo da revista tenham apresentado menor efeito de desejabilidade social. Esse tipo de material de pesquisa permite às pessoas manifestarem em seu posicionamento contra essa política social, uma posição contrária à defendida pelo artigo da revista, sem receio quanto às consequências sociais de serem recriminados pela diferença dessa posição com aquela desejada socialmente ou politicamente correta.

A fim de ampliar o conhecimento sobre as representações sociais acerca desse objeto, seria necessário realizar a pesquisa em diversos contextos sociais e culturais, considerando as variáveis que caracterizam os participantes e os contextos onde eles expressam suas teorias leigas sobre esse tipo de objeto social. A utilização da técnica de grupos focais, em futuras pesquisas, possibilitaria avaliar o efeito do conteúdo de diversas notícias e artigos de revistas em relação à elaboração de representações sociais. 


\section{Referências}

AUGOUSTINOS, M.; TUFFIN, K.; EVERY, D. New racism, meritocracy and individualism: Constraining affirmative action in education. Discourse \& Society, v. 16, n. 3, p. 315-340, 2005.

AZEVEDO, C. M. M. Cota racial e estado: abolição do racismo ou direitos de raça?. Cadernos de Pesquisa, v. 34, n. 121, p. 213-239, 2004.

BALBINO, A. B. O caráter democrático das ações afirmativas: considerações sobre os impactos sociais da implementação das políticas de cotas na UERJ e suas possíveis contribuições ao processo de democratização do ensino no Brasil. 2004. Dissertação (Mestrado) - Faculdade de Educação, Universidade Federal do Rio de Janeiro, UERJ, Rio de Janeiro, 2004.

BAYMA, F. Constitutionality regarding racial quotas in public universities in Brazil: international approach and post-trial'challenges. Ensaio: Avaliação e Políticas Públicas em Educação, v. 20, n. 75, p. 325-346, 2012.

BARROS, E. de S.; BARROS, C. C. da S.; RÊGO, B. F. As ações afirmativas e seus aspectos jurídicos e sociais: o caso das cotas para afro-descendentes nas universidades públicas brasileiras. Revista da Faculdade de Direito da UFG, v. 33, n. 2, p. 236/247, 2010.

BITTAR, M.; ALMEIDA, C. E. Myths and controversies on the policies of quotas for blacks in higher education. Educar em Revista, n. 28, p. 141-159, 2006.

BRANDÃO, A. A.; DE MARINS, M. T. A. Cotas para negros no Ensino Superior e formas de classificação racial. Educação e Pesquisa, v. 33, n. 1, p. 27-45, 2007.

CAMARGO, B. V. A televisão como vetor de difusão de informações sobre a AIDS. Representações sociais: Abordagem interdisciplinar, p. 130-152, 2003.

CAMARGO, B. V. ALCESTE: um programa informático de análise quantitativa de dados textuais. Perspectivas teórico-metodológicas em representações sociais, v. 1, p. 511-539, 2005.

CAMARGO, B. V.; JUSTO, A. M. IRAMUTEQ: um software gratuito para análise de dados textuais. Temas em Psicologia, v. 21, n. 2, p. 513-518, 2013.

CONTARELLO, A. Representações sociais e o mundo da ciência: Gênero, número e caso em ciência, tecnologia e vida cotidiana. Joao Pessoa: Editora Universitária da UFPB, 2007. p. 203-222.

DOISE, W. Les représentations sociales: définition d'un concept. Connexions, 1985.

DURHAM, E. Desigualdade educacional e cotas para negros nas universidades. Novos Estudos CEBRAP, n. 66, p. 3-22, 2003. 
GUIMARÃES, A. S. A. Racismo e anti-racismo no Brasil. São Paulo: Editora 34 LTDA, 1999.

JODELET, D. Representações sociais: um domínio em expansão. As representações sociais, p. 17-44, 2001.

KIENTZ, A. Comunicação de massa: análise de conteúdo. Rio de Janeiro: Eldorado, 1973.

LORENZI-CIOLDI, F. Les représentations des groupes dominants et dominés: Collections et agrégats. Grenoble: Presses Universitaires, 2002.

LORENZI-CIOLDI, F.; BUSCHINI, F. Vaut-il mieux être une femme qualifiée ou être qualifiée de femme? Effets paradoxaux de la catégorisation dans la discrimination positive. Autre, Regards psychosociaux, p. 279-308, 2005.

MOEHLECKE, S. Ação afirmativa: história e debates no Brasil. Cadernos de pesquisa, v. 117, p. 197-217, 2002.

MOSCOVICI, S. Das representações coletivas às representações sociais: elementos de uma história. In: JODELET, D. (Org.). As representações sociais. Tradução de Lílian Ulup. Rio de Janeiro: EdUERJ, 2001.

2003.

. Representações sociais: investigações em psicologia social. Vozes,

Social cognition: On social representation. In: FORGAS, J. P. (Ed.).

Social Cognition: Perspectives in Everyday Understanding. London: Academic Press, 1981.

MUNANGA, K. A difícil tarefa de definir quem é negro no Brasil. Estudos Avançados, v. 18, n. 50, p. 51-66, 2004.

MUNANGA, K. Políticas de ação afirmativa em benefício da população negra no Brasil: um ponto de vista em defesa de cotas. Sociedade e cultura, v. 4, n. 2, 2007.

NAIFF, D. G. M.; NAIFF, L. A. M.; SOUZA, M. A. de. As representações sociais de estudantes universitários a respeito das cotas para negros e pardos nas universidades públicas brasileiras. Estudos e Pesquisas em Psicologia, v. 9, n. 1, 2009.

NEVES, P. S.C.; LIMA, M. E. O. Percepções de justiça social e atitudes de estudantes pré-vestibulandos e universitários sobre as cotas para negros e pardos nas universidades públicas. Revista Brasileira de Educação, v. 12, n. 34, p. 17-38, 2007.

PALMONARI, A.; CERRATO, J. Representações sociais e psicologia social. Teoria das representações sociais, v. 50, p. 305-332, 2011. 
QUEIROZ, D. M.; SANTOS, J. T. dos. Sistema de cotas: um debate. Dos dados à manutenção de privilégios e de poder. Educação e Sociedade, v. 27, n. 96, p. 717737, 2006.

RODRIGUES, W. G. Dilemas da ação afirmativa: ou democratização da universidade pública por meio do sistema de cotas ou manutenção da qualidade do ensino. Revista Formadores, v. 1, n. 3, p. 433, 2006.

ROUQUETTE, M.-L. La comunicación de masas. In: MOSCOVICI, S. (Org.). Psicología Social II. Buenos Aires: Paidós, 1986.

RÜDIGER, F. As teorias da comunicação. Porto Alegre: Penso, 2011.

SEGALLA, A.; BRUGGER M.; CARDOSO, R. Por que as cotas raciais deram certo no Brasil. Revista ISTOÉ, Editora 3, Edição 2264 de 05 de abril de 2013. Disponível em

http://www.istoe.com.br/reportagens/288556_POR+QUE+AS+COTAS+RACIAIS+DE RAM+CERTO+NO+BRASIL ?pathlmagens=\&path=\&actualArea=internalPage .

Acesso em 05 jul. 2013.

SILVA, P. B.; SILVA, P. da. Representação Social de Estudantes Universitários sobre Cotas na Universidade. Fractal: Revista de Psicologia, v. 24, n. 3, p. 525542, 2012.

TAJFEL, H. La catégorisation sociale. In: MOSCOVICI, S. (Org.). Introduction à la psychologie sociale. Paris: Larousse, 1972. p. 272-302. 1 v.

TAJFEL, H. Grupos humanos e categorias sociais-II. Lisboa: Livros Horizonte, 1983. p. 189-418.

TRAGTENBERG, M. H. R. et al. Como aumentar a proporção de estudantes negros na universidade. Cadernos de Pesquisa, v. 36, n. 128, p. 473-495, 2006.

WACHELKE, J. F. R.; CAMARGO, B. V. Representações sociais, representações individuais e comportamento. Interamerican Journal of Psychology, v. 41, n. 3, p. 379-390, 2007.

WOLF, M. Teorias da comunicação. 5. ed. Lisboa: Editorial Presença, 1999.

Artigo:

Recebido em: 30/10/2013

Aceito em: 22/07/2014 